\title{
Editorial
}

\section{Women's changing economic activity: implications for care of the elderly}

Since the beginning of this century, there has been a rapid increase in the population of elderly people in developed countries. In the UK, for example, between 1901 and 1981, the number of people aged over 65 rose from 1.7 million to more than eight million. ${ }^{1}$ Such an increase, striking in absolute and proportionate terms, constitutes a trend that is set to continue.

Whilst the advent of the NHS in 1948 and subsequent developments formalized state responsibility towards the frailer minorities of the population, ${ }^{2}$ care of the elderly has long taken place within the family, and continues to do so. ${ }^{3}$ The rising demand for care has major implications for women, since 'informal' care or 'family' care can most accurately be translated into care by the nearest female relative. ${ }^{4}$ Moreover, of the six million carers in the UK today, two-thirds are individuals shouldering the main responsibility for care of the elderly relative. ${ }^{5}$ It appears that these primary carers are central to the maintenance of the elderly in the community, an objective that has risen in popularity with the government and other agencies in recent years. An understanding of the experiences, needs and aspirations of these and future female carers is therefore crucial to the construction of well informed community care policy.

Perhaps the broadest socio-economic trend to have occurred in the last century in the lives of women has been the massive increase in those in paid employment. This trend is potentially the most important element in the changing supply and demand equation of the care of the elderly.
Women's participation in economic activity has been increasing since the $1960 \mathrm{~s} .{ }^{6}$ Most of this rise has been accounted for by increasing proportions of women returning to work after having children. Apart from women in their teens, those in their forties have the highest employment rates of all women (78\%). ${ }^{6}$ As a result of the falling birth rate, the number of young people entering the labour market is decreasing. It is therefore predicted that women in middle age will constitute the bigger growth area in the labour market up to the end of the twentieth century. However, it is precisely during these years of their lives in which women are most likely to face the responsibility of caring for older relatives.

Conflicts are inevitable. Since they are the mainstay of community care policies, women are required to stay at home to care for elderly relatives. Women are also needed to maintain the size of the labour force in an era of an aging population. The latter requirement may affect women's ability to care. Caring for the elderly relative fulfils the traditional attitudes and assumptions that a woman's primary responsibility is the welfare of others. However, the last twenty years have seen the rise of new values - that women should be free to work outside the home if they wish. Changes in women's roles and their attitudes towards them may affect women's willingness to stay at home to care.

The 'role accumulation' theory proposes that paid employment has beneficial effects on mental health. ${ }^{7}$ It is suggested here that employment often broadens a woman's horizons, establishes 
greater financial security and enhances her feelings of individual identity and worth. Many women who are now in their sixties had little socialization towards the acquisition of the longterm work role, because for women in this age group today work training was minimalized by a value system that their 'natural' roles were those of wife, mother and housewife ${ }^{8}$ However, the orientation of women in the labour force and society has altered. Changes in the attitudes and societal needs open up career opportunities for women. This may well decrease the likelihood that future generations of women will be as willing to take on the heavy responsibility of caring for an elderly relative. If this is the case, the massive void that would be created in the provision of community care would have to be filled by formal services. Since community care policies rely heavily on the female principal carer, the compatibility of such responsibility and a woman's individual needs and aspirations require careful consideration.

Jeanette Potter, Medical Student, St Mary's Hospital Medical School, Norfolk Place, London W2 IPG, UK.

\section{References}

1 Henwood M, Wicks M. The forgotten army: family care and elderly people. Family Policy Studies Centre, 1984.

2 Cherlin A. A sense of history: recent research on ageing and the family. In: Riley MW, Hess BB, Bonds K eds. Ageing and society: selected reviews of recent research. London: RKP, 1983.

3 Land H. Who cares for the family? J Soc Policy 1982; 7: 257-84.

4 Wild S. Women and caring. Meridian 1983; 2 : 11-14.

5 OPCS. Informal carers. In: General household survey. London: HMSO, 1985.

6 Martin J, Roberts C. Women and employment: a lifetime perspective. London: OPCS, 1984.

7 Arber SG, Gilbert H, Dale A. Paid employment and women's health: a benefit or a source of role strain? Sociol Health Illness 1985; 7: 375-99.

8 Lopata HZ, Steinhart FS. Work histories of American urban women. Gerontologist 1971; 11: 27-33. 